\title{
MARITIME ENGLISH TEACHING IN THE MIDDLE OF SEAFARER'S ISSUES AND GLOBAL MARITIME OPPORTUNITY
}

\author{
Sri Sartini \\ Maritime Academy of Yogyakarta, Indonesia
}

\begin{abstract}
Indonesia is an archipelago country with thousand-pretty blessed islands with large hinterland surround. Regarding the fact, many of Indonesian believes that their ancestor is seafarer. Many Indonesian live from sea. They live from everything provided by the wealth of the seas. Fortunately, the government realizes this fact and they believe that maritime potential of country could be explored well for the sake of people's wealth and welfare. This is done by their commitment to growing up and securing maritime higher education by following the international standard of IMO which is called as STCW 2010 Manila amendment. Data was stated that in this recent year, the world needs more than 69.241 qualified seafarers for each five years later. As the consequences, English is an obligatory to achieve. Maritime English which is more specific in the English subject would be an essential knowledge as well as skill in line with the issues. In the global maritime world, this competence should be effectively mastered by each seafarer as broad opportunity of qualified seafarers is always open for both national and international shipping companies. In this study, the writer obtain the knowledge and the data to support the paper by interviewing and sharing questionnaires to the senior seafarers who have excellent experiences at sea and in land who already signed off board from their sea projects. The results show that Maritime English teaching is absolutely needed because global maritime job opportunities in the recent year and in the future are engaging.
\end{abstract}

Keywords: maritime English, seafarer, global maritime opportunity

\section{INTRODUCTION}

Maritime sector is nowadays declared as a very potential issue in Indonesia in term of economic and welfare development for its people. Even Indonesian government reaffirms maritime as the main development sector which includes other sectors and one of which is education sector of maritime. Maritime education is strongly conducted to supply qualified candidates of seafarer and human resources who are proficiently mastered any kind of maritime affairs. In line with this fact, Indonesian government follows the regulation of International Maritime Organization through earlier adoption of the international Convention on Standard of Training Certification and Watch keeping for seafarers (STCW) 1978 amended as STCW Manila 2010. According to the regulation, every of maritime higher education should develop model training courses to assist the implementation of achieving more rapid transfer of information and skills regarding new developments in maritime technology. In addition, comprehensive set of English short courses would supplement the instruction provided by IMO regulation. IMO has therefore developed the current series of model courses in response to these generally identified needs and oblige that Maritime English courses in such maritime higher education will be fundamental to be held to produce qualified seafarers or mariners.

In reference to the IMO model course for Maritime English, IMO launched IMO Model Course 3.17. This model course was published as a guideline for assisting administrations to develop each maritime higher education training 
programs to achieve the standard for English set out in the STCW 1978 Manila amendment 2010. It is due to the basic requirement of English to be mastered in order to meet specific professional objectives. Seafarers or mariners candidates have abundant chances to join both national and international shipping lines whether they are local-going or even ocean-going vessels in which their English proficiency is mandatory to be used. Therefore capability of using English especially for communicative purposes as it is obliged by the international rule would be much important to achieve.

To meet the competencies of the seafarer candidates especially in term of the use of English both as their internal and external communication language as well as to meet the need of the maritime world, Maritime English teaching is urgently required to be professionally implemented in maritime higher education.

\section{LITERATURE REVIEW}

The important of mastering English cannot be neglected in today's global maritime opportunities. Therefore proficiency of comprehending and using the language is an obligatory. As it is stated by Johan Wolfgang Von Goethe in Nurajifah (2015) that someone who does not know foreign language does not know anything of their own. It means that in the middle of the need of English in shipping business which is never ending, the need of qualified seafarer is always increased by the time thus Maritime English teaching even becomes the most important language subject to teach.

Data which supports Indonesia as an archipelago country which has abundant chances in global maritime job opportunities states that more than 17.000 islands are a well-functioning shipping industry basis in which those shipping industry hold major role in Indonesia's trade furthermore in the global trade. The trade can be done via water, land, and air transportation. That is why maritime academy should include Maritime English teaching in the process of student learning. Dirgayasa (2014) mentions that in order to improve the quality of Indonesian Maritime Education and Trainings, the maritime English teaching must adopt and implement International curriculum issued and legalized by STCW 2010 to create qualified Indonesian seafarers. IMO Model Course 3.17 is the guidance that must be uphold in the teaching process. Dirjen Bobby (2014) in Rahmawati (2016) states that in 2020 shipping industry needs 1.593 .198 seafarers in entire world but in prediction it will only supplies around 1.555 .281 which means the shipping industry will still need 37.917 more seafarers. On the other word it can be said that the shipping industry is still need much more qualified seafarers for some years later.

It can be concluded that the needs of seafarers for world shipping industries is always open. To meet the need of the IMO standard as it is mentioned in STCW 2010 Manila Amendment, Maritime English teaching requires to be taught maximally. The regulation as it is mentioned in IMO Model Course 3.17 states that Maritime English teaching should cover language for communication. Communication based on Clampitt (2013) is the transmission and/or the reception of signals through some channel(s) that human interprets based on probabilistic system that is deeply influenced by context. The communication that should be mastered by seafarer are both internal communication and external communication. Therefore in the teaching process of maritime higher education and training it should include language system and language skills ( listening, speaking, reading, writing) which all activities are adapted from authentic maritime situations with choice of supplementary maritime topics provided in the Maritime focus sections of 
the core section 2. However, Setiyaningsih (2016) states that many seafarers have a problem in expressing themselves in English especially in using maritime terminologies for their communication. Thus communication skill should be improved by means of maritime English teaching which is properly done in teaching and learning process.

\section{DISCUSSION}

This paper discusses the result of the study did by the writer. In the study the writer shared many questionnaires and having a conversation with many lecturers who are already retired as seafarers so they are well-experienced and qualified become the participant or the source of information. Those participant were coming from deck as well as engine department. The point of the questions are as follows;

3.1 Indonesian Maritime Education and Training

Based on the result of the questionnaires shared, Indonesian maritime education and training requires guidance from the government to improve the quality in all aspects of maritime education and in the student's future work. The quality that should be achieved is set out as it is mentioned by the standard as required by IMO. Therefore Indonesian government through Directorate General of Sea Transportation as the IMO administration decides the policy for maritime education and training to conduct successful teaching and learning process.

3.2 Integrating Maritime Topic in Maritime English Teaching

Maritime English teaching in maritime higher education and training ideally should be done in line with the need of the students in their subject areas. Thus the model course that must be given is suited with the content-based input from the syllabi of the department. This will ensure that the English which the students (seafarer's candidate) learn at college incorporates technical subject as context for studying language. On the other hand, Maritime English teaching also should include or support the type of communication skills that the students need for other subject areas as well e.g. for report writing since officer on board should also be able to write a report for their company even during their voyage, log book writing, giving order to engine department, giving order to wheelhouse, etc.

Integrating maritime topic in maritime English teaching is mandatory. The output that is required for seafarer's candidate is all about proficiencies and competencies in manning the vessel, operating all the navigation aids, successful management of day to day running of vessel therefore all seafarer candidate must be competent with all maritime subject or topic. Comprehending maritime terminologies ease the working process on board vessel, thus it should not be ignored. From this explanation, it can be simply concluded that Maritime English is a type of English for specific purposes so that the teaching method also need to be well-explored.

\subsection{Standard Marine Communication Phrases (SMCP)}

In order to solve communication problems derived from language difficulties, IMO on its $22^{\text {nd }}$ Assembly launched Standard Marine Communication Phrases (SMCP) and has been systematically developed and nowadays regulated as Regulation A.918. The application of SMCP communication among crew members on ship and between ships and shore services is compulsory regulated by one of IMO convention namely Standard of Training Certification and Watchkeeping (STCW) and regulated by safety of Life at Sea (SOLAS) Convention. In the real teaching practice, maritime English teacher or lecturer must use two guidance. One of it is IMO Model Course 3.17 Maritime English in which it is a guideline for 
assisting trainers to develop their own programs to achieve the Standard of English as it is regulated by STCW 2010 Manila Amendment convention regulated by IMO. The second guidance is the use of SMCP. It is used to avoid miscommunication among crew member. The phrases are used by crew on board and crew on other ships or coastal stations. As it is guided in IMO Model Course 3.17 SMCP could be taught in many methods and teaching strategies based on the lecturer decision and creativeness.

In Maritime English teaching the main objective of the learning and teaching process is to get the students well understood with the maritime terminologies so that they could eliminate the problem of language difficulties on board vessel. The use of SMCP by the lecturer is an obligatory moreover for deck as well as engineer officer. Maximum exploration of SMCP usage enable students to be familiar with any order, instruction, and operational management on board vessel. Getting understood with all the terminologies written down in SMCP ease the officers on board doing all their duties including during watch keeping duties on bridge for deck officers and watch keeping duties in engine control room for engineer officers. 3.4 Global Working Opportunities for Seafarer

In fact the working opportunities in maritime sector both nationally and internationally are widely opened. However it depends on the seafarers candidates whether or not they could compete with other candidates from inner or outer countries. Recently with the globalization era and Asian Economic Community where there is no boundaries between human resources from inner or outer countries, they should be able to compete in order to get beneficial position in their job or working environment. In such situation, Maritime English Teaching which integrates the seafarer's competence as professional officers on board vessel and ability of communication in international language which means English has to be professional conducted.

Good mastery in English both in internal and external communication for officer on board vessel will help them to be well-occupied in such a good position in their company since the competition is not only regional-level but also international-level. Maritime working opportunities in regional level is shown by the fact that we are located in a strategic waterway business due to the close position to Indian and Pacific ocean. In fact Our country is one of the world largest maritime countries with 5.8 million square kilometers of sea territory while its land territory covers only 1.9 million square kilometers (Antara news,2015).

\section{CONCLUSION}

From the reality and the opinion from the experienced-person, Maritime English teaching in maritime-sector countries needs real and proper implementation as well as support from any aspect. The government as the policy maker should not only promote country as global maritime axis but also gives the real support and understand the needs of Indonesian maritime education and training itself. Indonesian government through Directorate General of Sea Transportation as IMO administration in Indonesia has their authority to manage all Indonesian maritime higher education and training to conduct their training program based on the IMO regulation. Therefore every maritime training and courses uphold their decision.

Maritime English Teaching which integrates the seafarer's competence in operating the vessel based on IMO or international regulation and capability of English language mastery becomes very mandatory to carry out. Moreover, in the middle of global maritime opportunities in which broaden chances of working 
experiences in entire the world are widely opened, Maritime English mastery is regarded to be achieved. In more specific understanding, Maritime English much uses specific terminologies that specifically used on board vessel. Furthermore, Maritime English teaching is regarded as English for specific purposes because the terminologies which are used on board vessel are different from any of English off board. In conclusion, Maritime English teaching will be very fundamental to teach and all of Maritime English lecturer must ensure that learners master the English communication being used on board vessel. It will lead to their future success since their working opportunities are much engaging.

\section{REFERENCES}

Antara News.2015. Indonesian Government Reaffirms Maritime as Main Development Sector. It was taken from www.antaranews.com.

Clampitt,P.G. 2013. Communicating for Managerial Effectiveness. Thousand Oaks, CA: Sage Publications, Inc.

Dirgayasa.2014.Survey of English Teaching and Learning Process in Maritime Education and Training in Indonesia: A case study in Private MET in Indonesia. English Language Teaching; Vol.7,No.7;2014.ISSN 19164742 E-ISSN 1916-4750 Published by Canadian Center of Science and Education.

International Maritime Organization.2010.Standard of Training Certification and Wacthkeeping Convention (STCW) Manila Amendment.

International Maritime Organization. 2000. IMO Model Course 3.17 Maritime English. London:IMO Publication

Nurajifah, Dian .2015. Penguasaan Bahasa Iggris Sebagai Komunikasi Internasional Untuk Menunjang Karir Ketika Bekerja. diannurajifah.blogspot.ci.id.

Rahmawati,Yussi.2016.Maritime Education and Training in the Middle of Government Support and Opportunity. Proceeding in $1^{\text {st }}$ International Conference On Maritime Education And Training (ICMET) 2016.ISBN 978-602-99381-7-3.

Setiyaningsih,Nita.2016.Back Chaining Drills to Improve The Cadets'practice of IMO Standard Marine Communication Phrases. Proceeding in $1^{\text {st }}$ International Conference On Maritime Education And Training (ICMET) 2016.ISBN 978-602-99381-7-3. 